\title{
STRATEGI PENGEMBANGAN AGRIBISNIS SAYURAN DI SULAWESI TENGGARA
}

\author{
Nurcayah \\ Fakultas Pertanian Program Studi Agribisnis \\ Universitas Muhammadiyah Kendari
}

\begin{abstract}
Abstrak
Tulisan ini bertujuan untuk mendeskripsikan potensi produksi sayuran dan lahan di Sulawesi Tenggara untuk penyusunan strategi pengembangan agribisnis sayuran dalam rangka menciptakan produk yang berkualitas dan bernilai tambah, untuk meningkatkan pendapatan dan kesejahteraan petani. Permasalahan utama dalam agribisnis sayuran adalah produksi dan produktivitas rendah, pemilikan lahan sempit, penanganan pascapanen masih tradisional, keterbatasan modal, infrastruktur terbatas, dan akses pemasaran kurang berkembang. Hasil analisis SWOT pada pengembangan agribisnis sayuran memperoleh empat strategi yang perlu dilakukan, yaitu: 1) strategi agresif ( $\mathrm{S} \square \mathrm{O}$ ), memaksimalkan potensi/kekuatan untuk meraih peluang dengan memanfaatkan teknologi produksi, perluasan lahan dan pangsa pasar, dukungan kebijakan pemerintah, penguatan kelembagaan, dan peningkatan kualitas SDM, 2) strategi diversifikasi $(\mathrm{S}-\mathrm{T})$, memaksimalkan potensi/kekuatan untuk mengurangi ancaman yang ada dengan melakukan kegiatan usaha tani yang ramah lingkungan, pemberdayaan penangkar benih, dan penerapan pengendalian hama terpadu (PHT), 3) strategi divestasi (W-O), meminimalkan kelemahan/hambatan untuk meraih peluang semaksimal mungkin melalui peningkatan produksi/produktivitas serta mutu produk, penguatan sarana usaha pertanian, diversifikasi, dan pengaturan pola tanam sesuai permintaan pasar, serta 4) strategi survival (WT), meminimalkan kelemahan dan hambatan untuk mengatasi ancaman dengan meningkatkan efisiensi biaya produksi, memperluas informasi pasar, dan mengoptimalkan pemakaian input kimia.
\end{abstract}

Kata kunci: Sayuran, agribisnis, analisis SWOT, Sulawesi Tenggara 


\begin{abstract}
This paper described land potential and production of vegetables in Southeats Sulawesi for preparation of vegetables agribusiness development strategy, that enabled to create high quality product, increase added value,efektif, efisien and improve farmers' income and welfare. The main problems found in vegetables agribusiness were low productivity, insufficient land ownership, traditional postharvest, lack of capital and infrastructure, and limiting market access. Result of SWOT analysis on vegetables agribusiness development found four strategies that can be applied, namely 1) aggressive strategy ( $\square \square O)$, maximizing the potency to reach maximum opportunity with proper technological application, extension of farm land and market share, government policy support, development of farmer institution, and increasing quality of human resources, 2) diversification strategy ( $\square \square T)$, maximizing the potency/ strength to overcome the existing threats by conducting environmentally friendly farming, empowering seed breeder, and applying integrated pest management, 3) divestation strategy $(W \square O)$, eliminating weaknesses to reach maximum opportunity by increasing production/productivity and product quality, improving infrastructure, product diversification and cropping pattern management according to market preferences, and 4) survival strategy $(W \square T)$, eliminating weaknesses and constraints to overcome threats through increasing production cost efficiency, extension of market information, and reducing synthetic chemical inputs use.
\end{abstract}

Keywords: Vegetables, Agribusiness, SWOT Analysis, Southeast Sulawesi

\title{
I. PENDAhuluan
}

Sayuran merupakan salah satu komoditas hortikultura yang memiliki peranan strategis dalam mendukung ketahanan pangan nasional dan berperan sebagai : 1) sumber bahan makanan bergizi bagi masyarakat; 2) merupakan sumber pendapatan dan kesempatan kerja; 3) sebagai komoditas potensial ekspor yang merupakan sumber devisa negara; serta 4) memiliki peluang pasar bagi sektor non pertanian, khususnya industri hulu. Nilai ekspor sektor pertanian pada tahun 2018 berdasarkan data Badan Pusat Statistik subsektor hortikultura berada di posisi tertinggi kedua setelah subsektor perkebunan. Hal ini dapat dikatakan bahwa subsektor hortikultura memiliki kontribusi yang besar pada ekspor di sektor pertanian. ekspor Dari beragamnya komoditas subsektor hortikultura, terdapat 10 komoditas produk hortikultura (segar) dengan nilai terbesar. Menurut Badan Pusat Statistik (BPS) Produksi subsektor hortikultura pada tahun 2018 untuk komoditas buah-buahan mencapai 21,5 juta ton, komoditas sayuran mencapai 13 juta ton, tanaman hias 870 juta tangkai, dan tanaman obat mencapai 676 ribu ton. Pemerintah melalui Kementerian Pertanian melakukan peningkatan produksi subsektor hortikultura dengan berbagai program, salah satunya yaitu penguatan sistem seperti memperbaiki sistem distribusi, logistik, dan untuk memasarkannya 
Kontribusi agribisnis sayuran pada tahun 2018 terhadap pembentukan PDB sub sektor hortikultura 36,07 \% berarti Tanaman sayuran besar peranannya dalam perekonomian negara. Oleh karena itu perlu adanyan strategi pengembangan sayuran untuk meningkatkan perekonomian wilayah, yang pada akhirnya akan meningkatkan daya saing wilayah. Survei Pertanian Hortikultura Tanaman Sayuran dan Buah-Buahan Semusim Produksi sayuran indonesia mencakup 22 (dua puluh dua) jenis tanaman sayuran semusim dan 4 (empat) jenis tanaman buah-buahan semusim. Tahun 2018, lima komoditas sayuran semusim dengan produksi terbesar secara berurutan adalah bawang merah, kubis, cabai rawit, kentang, dan cabai besar. Produksi nasional bawang merah mencapai 1,5 juta ton, kubis mencapai 1,41 juta ton, cabai rawit mencapai 1,34 juta ton, kentang mencapai 1,28 juta ton, dan cabai besar mencapai 1,21 juta ton. Produksi bawang merah, cabai rawit, kentang, dan cabai rawit pada tahun 2018 mengalami peningkatan dibandingkan tahun 2017. Hanya produksi kubis pada tahun 2018 mengalami penurunan dibandingkan tahun sebelumnya. Tahun 2018, tercatat sebanyak 17 (tujuh belas) jenis sayuran semusim yang diekspor oleh Indonesia, yaitu bawang merah, bawang putih, kacang merah, kembang kol, kentang, kubis, lobak, wortel, bayam, buncis, cabai besar, jamur, kacang panjang, ketimun, labu siam, terung, dan tomat. Total nilai ekspor sayuran semusim tahun 2018 mencapai 11,82 juta US \$. Komoditas yang menjadi penyumbang devisa terbesar adalah bawang merah dengan jumlah berat bersih 5,22 ribu ton dan nilai ekspor sebesar 6,29 juta US \$.

Provinsi Sulawesi Tenggara Tahun 2018 Kontribusi sektor pertanian masih sangat besar peranannya mencapai 24,08 persen dalam pertumbuhan ekonomi, namun kontribusi subsektor hortikultura sebesar $0,96 \%$ daerah salah satu diantaranya Tanaman sayuran. Untuk itu produksi Tanaman hortikultura khususnya tanaman sayuran masih perlu dikembangkan dalam mencapai ketahanan pangan tahun 2024. Provinsi Sulawesi Tenggara tahun 2018 memproduksi berbagai jenis sayuran namun yang memiliki produksi yang paling besar adalah cabai rawit 44.482 kuintal, Terong 38.700 kuintal dan Tomat 37.911 kuintal. Namun berdasarkan data sebagian besar penduduk Indonesia mengkonsumsi buah dan sayur sebanyak 173 gram per hari termasuk penduduk Provinsi Sulawesi Tenggara, lebih kecil dari Angka Kecukupan Gizi (AKG) yang direkomendasikan yaitu sebesar 400 gram perkapita per hari. (Buletin Pemantauan Ketahanan pangan Indonesia Tahun 2017). 
Menurut BPS Sulawesi Tenggara ,Pada Tahun 2017 beberapa komoditas sayur-sayuran semusim mengalami penurunan luas panen dibandingkan tahun sebelumnya antara lain bayam, buncis, jamur, kacang panjang, kangkung, ketimun, labu siam, terung, dan tomat, berbeda dengan komoditas sayuran lainnya yang mengalami penurunan, sedangkan tanaman bawang daun, bawang merah, cabai besar, dan cabai rawit mengalami peningkatan dibanding tahun sebelumnya.. Kegiatan agribisnis sayuran di Sulawesi Tenggara menghadapi berbagai masalah,seperti produksi dan produktivitas rendah masih jauh dari bawah standar potensial, pemilikan lahan sempit, penerapan teknologi pascapanen masih lemah, serangan hama dan penyakit tanaman, pemilikan modal terbatas, infrastruktur belum memadai, dan akses pemasaran yang kurang, rendahnya mutu hasil dan harga panennya sangat ditentukan oleh pembeli. Menyikapi masalah/ kelemahan tersebut dan adanya tantangan pasar bebas, pada masa mendatang para pelaku usaha perlu mengembangkan agribisnis yang mampu merespons pasar dengan menawarkan produk yang berdaya saing. Oleh karena itu pengembangan Kawasan Agribisnis Hortikultura, termasuk kawasan sayuran daun yaitu menciptakan agribisnis sayuran yang efektif, efisien, berdampak bagi kemajuan dan kesejahteraan masyarakat yang terlibat di dalamnya diperlukan volume, intensitas dan kualitas kegiatan yang memadai berbasis pada kesamaan kegiatan dalam ruang yang sama. Untuk itu diperlukan sinergisme intra dan/atau antar wilayah, sejauh wilayah tersebut merupakan suatu kesatuan yang utuh secara ekonomis, yang dapat dibatasi oleh kemiripan agroekosistem dan kesatuan infrastruktur, sehingga akan dihasilkan dampak ekonomi yang nyata dan terukur, segala pelayanan dan fasilitasi di dalamnya dapat berjalan efektif dan efisien. Oleh karena itu perlu disusun strategi yang tepat dan terencana agar pengembangan agribisnis sayuran di Sulawesi Tenggara memberi dampak ekonomi nyata dan terukur terhadap pembangunan ekonomi masyarakat Sulawesi Tenggara maupun pembangunan nasional pada umumnya.

Tulisan ini bertujuan mendeskripsikan potensi produksi sayuran dan lahan di Sulawesi Tenggara untuk menyusun strategi pengembangan agribisnis sayuran dalam rangka menciptakan agribisnis sayuran produk yang berkualitas dan bernilai tambah, yang efektif, efisien, berdampak dan untuk meningkatkan pendapatan dan kesejahteraan petani.. Ruang lingkup tulisan mencakup analisis SWOT agribisnis sayuran, kebijakan pemerintah dalam sektor pertanian agribisnis, varietas unggul dan perbaikan teknik budi daya, serta prospek dan arah pengembangan agribisnis. 


\section{KAJIAN TEORI}

Analisis SWOT bertujuan menganalisis potensi/kekuatan, kelemahan, peluang, dan ancaman agribisnis sayuran di Sulawesi Tenggara. Potensi dan kelemahan merupakan faktor internal, sedangkan peluang dan ancaman merupakan faktor eksternal. Analisis SWOT digunakan untuk mengidentifikasi berbagai faktor secara sistematis untuk merumuskan strategi kegiatan. Analisis dilakukan untuk memaksimalkan kekuatan (strength), peluang (opportunities), serta meminimalkan kelemahan (weaknesses) dan ancaman (threats). Proses pengambilan keputusan selalu berkaitan dengan pengembangan misi, tujuan, strategi, dan kebijakan. Dengan demikian, perencanaan strategis harus menganalisis faktor-faktor strategi kegiatan (kekuatan, kelemahan, peluang, dan ancaman) sesuai kondisi saat ini (Rangkuti 1997).

Lingkungan diartikan sebagai tempat yang tidak terlepas dari suatu kondisi, situasi, dan peristiwa yang memengaruhi perkembangan setiap usaha. Setiap pengelolaan usaha diupayakan sedapat mungkin menyederhanakannya melalui penyelidikan/observasi terhadap berbagai faktor lingkungan. Oleh karena itu, perlu ditetapkan kriteria untuk mempelajari lingkungan internal dan eksternal. Lingkungan memiliki pengaruh nyata terhadap kemungkinan keberhasilan dan kegagalan agribisnis sehingga timbul peluang dan ancaman usaha. Melalui analisis peluang maka strategi usaha dapat disusun dengan memerhatikan analisis faktor internal, yang terdiri atas unsur kekuatan dan kelemahan usaha tani. Dengan demikian, identifikasi kekuatan dan kelemahan diarahkan untuk mengeksploitasi peluang dan mengatasi ancaman.

Sebagai suatu kegiatan ekonomi, usaha tani sayuran tidak terlepas dari pengaruh lingkungan, yaitu faktor internal dan eksternal. Faktor internal terdiri atas pendidikan sumber daya manusia, pro- duktivitas, modal, tenaga kerja, dan pengalaman berusaha tani, sedangkan faktor eksternal meliputi kelembagaan, pemasaran, infrastruktur, dan kebijakan pemerintah. Menurut Hendayana (2011), ada tiga tahap kegiatan yang dilakukan dalam analisis SWOT, yaitu 1) pengumpulan data, 2) analisis data, dan 3) penyusunan strategi. 


\section{METODOLOGI PENELITIAN}

Penelitian ini dilaksanakan di Provinsi Sulawesi Tenggara denga menggunakan data sekunder dan data primer melalui wawancara dengan beberapa petani sayuran yang ada di beberapa Kabupaten Provinsi Sulawesi Tenggara. Analisis dalam penelitian ini menggunakan Analisis SWOT.

\section{HASIL DAN PEMBAHASAN}

Berdasarkan hasil analisis SWOT, dapat dikemukakan beberapa strategi pengembangan agribisnis sayuran di Sulawesi Tenggara sebagai berikut:

A. Strategi S-O: memaksimalkan potensi/kekuatan untuk meraih peluang. Strategi ini bersifat agresif, meliputi a) pemanfaatan teknologi produksi, b) perluasan lahan dan pangsa pasar, c) kebijakan pemerintah/pengembangan kelembagaan usaha agribisnis, dan d) peningkatan kualitas SDM . Menurut Maddolangan (2005), petani yang berpendidikan akan lebih mudah menyerap materi pelatihan dibandingkan dengan petani yang tidak berpendidikan.

B. Strategi S-T: memaksimalkan potensi/kekuatan untuk mengatasi ancaman. Strategi ini mengarah pada upaya diversifikasi, terdiri atas a) usahatani ramah lingkungan, b) pemberdayaan penangkar benih, dan c) penerapan komponen pengendalian hama terpadu (PHT).

C. Strategi W-O: meminimalkan kelemah an/hambatan untuk meraih peluang. Strategi ini bermakna investasi atau divestasi, meliputi a) peningkatan produksi/produktivitas serta mutu produk, b) penguatan sarana usaha pertanian (pengembangan kios saprodi, perbaikan jalan usaha tani, penyediaan irigasi, pemanfaatan alat dan mesin pertanian, penyediaan pupuk), pemanfaatan lembaga keuangan mikro, optimalisasi skim kredit perbankan dan nonperbankan, dan c) diversifikasi dan pengaturan pola tanam sesuai permintaan pasar.

D. Strategi W-T: meminimalkan kelemahan dan hambatan untuk mengatasi pengaruh ancaman. Strategi ini ber- sifat defensif atau bertahan, meliputi a) efisiensi biaya produksi, b) perluasan informasi pasar, c) dan meminimalkan pemakaian input kimia. 
1. Kebijakan Pemerintah Dalam Pengembangan Agribisnis

Perhatian Pemerintah Provinsi Sulawesi Tenggara terhadap pembangunan pertanian yang diimplementasikan melalui dukungan melakukan nota kesepahaman dengan Kementerain Pertanian yang terdiri dari enam poin : Perlindungan Sumber Daya Alam dan Plasma Nutfah (Sumber Daya Genetik) Sulawesi Tenggara, Penyiapan benih bersama antara Pemerintah Provinsi Sulawesi Tenggara dengan Kementerian Pertanian; Penyiapan infrastruktur ekspor produk pertanian; Bimbingan teknis dalam penanganan pasca panen; Pengoptimalan produktivitas lahan dan Akses pasar internasional. Kebijakan ini dimaksudkan untuk mewujudkan kondisi lingkungan yang kondusif, kelembagaan pemerintah dan masyarakat yang andal, serta mendukung peningkatan perekonomian wilayah dan kesejahteraan masyarakat dengan memanfaatkan seluruh potensi daerah.

Meskipun pemerintah telah memberikan perhatian terhadap sektor pertanian, masyarakat petani/pelaku pembangunan pertanian belum banyak menikmati hasil yang menggembirakan, terutama dari aspek peningkatan pendapatan dan kesejahteraan. Hal ini disebabkan belum adanya jaminan pasar atau harga produk sayuran sehingga petani sulit memperoleh nilai tambah dari hasil usaha taninya. Di pihak lain, pengembangan agribisnis sayuran dengan pola kemitraan antara pengusaha dan petani/kelompok tani belum berkembang. Menurut Suwandi (1995) dan Taufik (2008), pengembangan agribisnis sayuran memerlukan empat pilar penunjang, yaitu: 1) eksistensi semua komponen agribisnis secara lengkap di kawasan sentra produksi, 2) terjalinnya kemitraan usaha antarpelaku agribisnis, 3) iklim usaha yang kondusif, dan 4) adanya gerakan bersama dalam memasyarakatkan agribisnis. Kondisi ini menjadi tantangan bagi pemerintah dan para pelaku usaha. Terlebih lagi dalam menghadapi globalisasi yang gejalanya sudah dirasakan dengan masuknya sayuran luar negeri, padahal daya saing sayuran dalamnegeri masih lemah, terutama dari segi kualitas. Untuk itu, perlu dibangun kemitraan usaha yang dapat meningkatkan daya saing secara berkelanjutan (Saptana et al. 2009).

Strategi pengembangan agribisnis sayuran di Sulawesi Tenggara diarahkan pada upaya pengembangan produksi yang berkualitas sesuai dengan kebutuhan, penciptaan pola tanam/pola produksi yang merata sepanjang tahun, peningkatan daya saing, peningkatan 
kemampuan SDM dan kesempatan kerja, penguatan kelembagaan petani, permodalan dan pemasaran melalui penguatan manajemen dan pengelolaan lembaga keuangan pertanian dan sentra penjualan atau pasar produk-produk pertanian harus menjadi perhatian khusus pemerintah. Termasuk perbaikan jalur niaga yang lebih menguntungkan atau berpihak pada kesejahteraan petani. Langkah yang krusial dan mendesak adalah memotong pemain-pemain di sektor hulu dan hilir, terutama bagi mereka yang hanya mengambil keuntungan dari aktivitas pertanian tanpa mempertimbangkan kesejahteraan petani. Yaitu dengan regulasi tata niaga pertanian yang mampu memberikan nilai tambah, serta pengoptimalan penggunaan lahan secara lestari dan dukungan sarana prasarana.

Sasarannya adalah terpenuhinya produksi sayuran yang sesuai standar mutu dan gizi, aman dikonsumsi, dan terciptanya lingkungan yang nyaman. Pengembangan agribisnis diarahkan pada upaya peningkatan pendapatan petani, terutama yang berbasis ekonomi kerakyatan di pedesaan (Saptana et al. 2002; Sutrisno 2003). Jenis tanaman yang cukup potensial di daerah Sulawesi Tenggara adalah cabai rawit, kacang panjang, Petsai, ,terung, dan tomat. Tanaman tanaman potensial tersebut dapat ditemui hampir diseluruh wilayah Sulawesi Tenggara, tetapi daerah yang sangat potensial adalah Muna dan Konawe Selatan. Untuk memenuhi kebutuhan tersebut, pemerintah memprioritaskan strategi pengembangan sayuran melalui ekstensifikasi di daerah yang sesuai serta intensifikasi dan diversifikasi di sentra-sentra produksi.. Berikut Luas Panen tanaman sayuran di Provinsi Sulawesi Tenggara tahun 2016 
Luas Panen Tanaman Sayuran Menurut Kabupaten/Kota dan Jenis Sayuran di Provinsi Sulawesi Tenggara (Hektar), Tahun 2016

\begin{tabular}{|c|c|c|c|c|c|c|c|c|c|c|c|c|}
\hline $\begin{array}{c}\text { Kabupaten/ } \\
\text { Kota }\end{array}$ & $\begin{array}{c}\text { Bawang } \\
\text { Merah }\end{array}$ & $\begin{array}{c}\text { Cabai } \mathbf{R} \\
\text { awit }\end{array}$ & Kubis & $\begin{array}{c}\text { Kacang } \\
\text { Panjang }\end{array}$ & Petsai & $\begin{array}{c}\text { Cabai } \\
\text { Besar }\end{array}$ & $\begin{array}{c}\text { Bawang } \\
\text { Daun }\end{array}$ & Tomat & Terung & Buncis & Ketimun Lainnya \\
\hline
\end{tabular}

\section{Kabupaten}

\begin{tabular}{|c|c|c|c|c|c|c|c|c|c|c|c|c|}
\hline 1 & Buton & 2 & 48 & 48 & 76 & 50 & 30 & 19 & 105 & 56 & 36 & 43 \\
\hline 2 & Muna & 3 & 155 & 11 & 307 & 37 & 27 & 13 & 225 & 201 & 4 & 20 \\
\hline 3 & Konawe & - & 77 & - & 111 & 36 & 71 & 12 & 83 & 70 & 5 & 41 \\
\hline 4 & Kolaka & 4 & 114 & 28 & 145 & 86 & 53 & 64 & 85 & 100 & 15 & 77 \\
\hline 5 & $\begin{array}{l}\text { Konawe } \\
\text { TENGGARA }\end{array}$ & - & 170 & 2 & 230 & 54 & 123 & 30 & 122 & 158 & 75 & 107 \\
\hline 6 & Bombana & - & 74 & - & 160 & - & 40 & 11 & 138 & 114 & - & 49 \\
\hline 7 & Wakatobi & 23 & 7 & - & 33 & 22 & 1 & - & 17 & 26 & 1 & 11 \\
\hline 8 & Kolaka Utara & 72 & 124 & 13 & 117 & 66 & 39 & 6 & 103 & 91 & 8 & 45 \\
\hline 9 & Buton Utara & - & 7 & - & 53 & - & 10 & - & 31 & 38 & - & - \\
\hline
\end{tabular}


Jurnal: Inovasi Sains dan Teknologi (INSTEK)

ISSN: 2655-0563, Edisi: Vol 2, No 2, Agustus 2019

\begin{tabular}{|c|c|c|c|c|c|c|c|c|c|c|c|c|c|}
\hline 10 & Konawe Utara & - & 24 & 1 & 41 & 4 & 14 & - & 24 & 28 & - & 19 & 52 \\
\hline 11 & Kolaka Timur & 22 & 97 & 25 & 177 & 71 & 72 & 34 & 158 & 147 & 28 & 104 & 384 \\
\hline 12 & Konawe Kepulauan & - & 5 & - & 4 & - & - & - & 6 & 6 & - & - & 3 \\
\hline 13 & Muna Barat & - & 46 & - & 133 & 34 & 33 & 30 & 82 & 55 & - & 57 & 199 \\
\hline 14 & Buton Tengah & - & 14 & 4 & 28 & 4 & 2 & - & 44 & 50 & - & 21 & 54 \\
\hline 15 & Buton TENGGARA & 24 & 5 & - & 14 & 9 & 3 & - & 22 & 8 & 3 & 5 & 47 \\
\hline \multicolumn{14}{|c|}{ Kota } \\
\hline 1 & Kendari & - & 64 & 2 & 69 & 47 & 18 & 7 & 53 & 79 & 6 & 14 & 326 \\
\hline 2 & Baubau & 8 & 15 & 8 & 35 & 23 & 11 & 1 & 34 & 31 & - & 16 & 36 \\
\hline \multicolumn{2}{|r|}{ Sulawesi Tenggara } & 154 & 1056 & 142 & 1733 & 543 & 547 & 227 & 1322 & 1258 & 181 & 629 & 3963 \\
\hline
\end{tabular}

Sumber data : Statistik Produksi Tanaman Hortukultura Provinsi Sulawesi Tenggara Tahun 2017 
2. Penanaman Varietas Unggul dan Perbaikan Teknik Budi Daya

Sayuran yang ditanam di Sulawesi Tenggara pada umumnya tanaman sayuran yang tumbuh didataran rendah karena suhu udaranya panas sehingga cocok untuk tanaman yang membutuhkan kelembaban udara rendah, Misalnya cabai, kangkung, bayam, kacang panjang,terong dan tomat, dll. Menurut BPS Sulawesi Tenggara ,Pada Tahun 2017 beberapa komoditas sayur-sayuran semusim mengalami penurunan luas panen dibandingkan tahun sebelumnya antara lain bayam, buncis, jamur, kacang panjang, kangkung, ketimun, labu siam, terung, dan tomat, , sedangkan tanaman bawang daun, bawang merah, cabai besar, dan cabai rawit mengalami peningkatan dibanding tahun sebelumnya. Jenis tanaman yang cukup potensial di daerah Sulawesi Tenggara adalah bayam, cabai rawit, kacang panjang, kangkung, terung, dan tomat. Tanaman - tanaman potensial tersebut dapat ditemui hampir diseluruh wilayah Sulawesi Tenggara, tetapi daerah yang sangat potensial adalah Muna dan Konawe selatan.

Kementarian pertanian mendorong Pemerintah Provinsi di Sulawesi Tenggara mengembangkan tanaman hortikultura dalam kunjunganya di Kab, Konawe Selatan Direktorat Jenderal Hortikultura Kementerian Pertanian (Kementan) berkomitmen mendorong peningkatan produksi petani, khususnya untuk komoditas hortikultura seperti bawang merah dan cabai. Direktorat Jenderal Hortikultura optimistis, ke depan Kabupaten Konawe Selatan bisa memacu produktivitas bawang merahnya serta menjadi lumbung komoditas hortikultura di Sulawesi Tenggara.

Menurut Nanda cardilla dalam Upaya peningkatan Produksi cabai Tahun 2018. Dalam budi daya cabai, produktivitas yang tinggi dapat dicapai bila petani menggunakan varietas unggul, pegolahan lahan sampai pemupukan namun cara yang lain adalah pemangkasan tunas, mikroba penyubur dan pemupukan yang tepat. Selanjutnya cara yang lebih cepat untuk mendapatkan varietas unggul ialah dengan mengintroduksikan dan menanam varietas cabai yang sesuai dengan keadaan setempat (Duriat 1995).

Produktivitas cabai rawit maupun cabai besar di Sulawesi Tenggara masih tergolong rendah dan cabai besar berfluktuasi antara 21,27 kwintal/ha bila jauh lebih rendah dibandingkan dengan produktivitas nasional yang mencapai 1,21 juta t/ha sedangkan cabai rawit sebesar 23,58 kwintal/Ha ebih rendah dibandingkan dengan produktivitas nasional yang 
mencapai 1,15 juta ton/ha (BPS Sulawesi Tenggara Tahun 2018); salah satu jenis dikembang beberapa kabupaten antara lain Kab. Konawe Selatan yaitu cabai besar varietas darmais dan cabe rawit yaitu varietas super putih. Menurut Dinas Pertanian perkebunan dan Hortikultura Sulawesi Tenggara Tahun 2018) rendahnya produktivitas tanaman hortikultura termasuk sayuran disebabkan oleh kurangnya bibit unggul, masih kurangnya prioritas terhadap pembinaan sumber daya manusia petani dan bahkan aparat pembinanya, kelembagaan petani belum berfungsi optimal serta penyelenggaraan pembangunan yang masih bersifat segmental-egosektoral. Selain itu, kelembagaan petani di desa umumnya belum berjalan dengan baik .

Sementara Produktivitas bawang merah di Sulawesi Tenggara baru mencapai 2.02 t/ha, jauh lebih rendah dari Produktivitas bawang merah nasional sekitar 9,31 t/ha (BPS dan Ditjen Hotikultura Tahun 2018). Produktivitas bawang merah masih dapat ditingkatkan apabila faktorfaktor yang mempengaruhi sistem usaha tani bawang merah, seperti tanah, iklim, teknologi produksi, permodalan, dan tenaga kerja dikelola secara optimal. Dari berbagai faktor yang memengaruhi produksi, pengelolaan sangat penting karena tanpa pengelolaan yang baik, usaha tani menjadi tidak efisien.

Selanjutnya Bawang merah merupakan tanaman yang banyak membutuhkan hara, baik pada masa pertumbuhan vegetatif maupun saat pembentukan, pembesaran, dan pematangan umbi. Cara paling umum untuk menyediakan hara bagi tanaman adalah dengan kegiatan pemupukan. Pemupukan bawang merah harus tepat jenis, tepat waktu, tepat cara, dan tepat kombinasi. Pemupukan yang tepat dan berimbang selain dapat memenuhi kebutuhan hara tanaman juga merupakan salah satu cara penting untuk meningkatkan ketahanan tanaman terhadap serangan hama dan patogen penyebab penyakit pada tanaman bawang merah (www.pertanian.com). Pemupukan dilakukan sebanyak tiga kali. Pemupukan pertama diberikan bersama ketika pengolahan tanah atau sebelum dilakukan penanaman bibit bawang merah. Jenis pupuk yang digunakan adalah kompos dan TSP dengan takaran masing-masing 1.000-2.000 dan $200 \mathrm{~kg}$ per hektare. Selanjutnya, pemupukan susulan pertama diberikan saat tanaman berumur 10-15 hst dengan jenis pupuk Urea (100 kg/ha), NPK 27/7/7 (100 kg/ha), Nitrabor (100 kg/ha), dan $\mathrm{KCl}$ (50 kg/ha). Pupuk susulan kedua diberikan saat tanaman berumur 20-25 hst dengan jenis pupuk NPK 16/16/16 (150 kg/ha), Kamas (100 kg/ha) dan $\mathrm{KCl}(50 \mathrm{~kg} / \mathrm{ha})$. 
Pengendalian hama secara hayati mampu menghemat penggunaan in- sektisida. Dengan rendahnya populasi hama, kehilangan hasil berkurang dan penggunaan insektisida dapat ditekan menjadi 1 liter/ha sehingga menghemat penggunaan insektisida 2 liter/ha atau senilai Rp200.000.

3. Agribisnis Sayuran di Kabupaten Konawe Selatan

Kabupaten Konawe Selatan terletak disebelah utara kota Kendari ibukota Provinsi Sulawesi Tenggara, ibukota Provinsi Sulawesi Tenggara dengan tofografi wilayahPermukaan tanah pada umumnya bergunung dan berbukit yang diapit oleh dataran rendah yang sangat potensial untuk pengembangan di sektor pertanian. Konawe Selatan termasuk salah satu daerah yang yang akan didorong oleh Kementan menjadi lumbung komoditi Hortikultura khususnya bawang merah, cabai dan tomat . Menurut Direktorat Jenderal Hortikultura Kementerian Pertanian (Kementan) Untuk komoditas cabai rawit misalnya, produksi petani setempat mampu mencukupi kebutuhan warga kabupaten berpenduduk 315.000 jiwa ini. Atau rata (panen) cabai rawitnya 6,9 ton per hektar, dengan luas tanam 152 hektar.

Artinya kalau dikalkulasikan 1.048 ton Ini sudah surplus karena kebutuhan cabai di sini (Konawe Selatan) hanya 878 ton. Adapun untuk bawang merah mengapresiasi upaya para petani dalam melakukan budidaya komoditas tersebut. Kendati baru memulai, ada semangat yang luar biasa dari para petani. "Luas tanamnya sekarang 7 hektar dengan total produksi sekitar 65 ton. Untuk kebutuhan (bawang merah) di Konawe Selatan sekitar 865 ton, dengan luas tanam 96 hektar," Direktorat Jenderal Hortikultura Kementerian Pertanian (Kementan) jelas optimistis, ke depan Kabupaten Konawe Selatan bisa memacu produktivitas bawang merahnya serta menjadi lumbung komoditas hortikultura di Sulawesi Tenggara. Oleh karena itu perlu ada pendampingan oleh petani, pemberian bahan organik karena tanah kecenderungan kandungan liatnya tinggi dan sinergi antara pemerintah pusat, daerah, petani dan penyuluh pertanian mampu mengakselerasi terwujudnya ketahanan dan kedaulatan pangan nasional.

4. Agribisnis Sayuran di Kabupaten Muna

Kabupaten Muna merupakan salah satu wilayah potensi pengembangan agribisnis sayuran. Berdasarkan Statistik Produksi Tanaman Hortikultura Di Sulawesi Tenggara Tahun 2017 Jenis tanaman yang cukup potensial di daerah Sulawesi Tenggara adalah bayam,cabai rawit, kacang panjang, kangkung, terung, dan tomat. Tanaman - tanaman potensial tersebut dapat 
ditemui hampir diseluruh wilayah Sulawesi Tenggara, tetapi daerah yang sangat potensial adalah Muna dan Konawe Selatan. Kab. Muna merupaka daerah yang potensial dengan komoditas andalannya ialah kacang panjang, tomat, dan terung. luas panen tanaman kacang panjang 286 hektar, tomat 213 hektar, dan terung 177 hektar. Kepala Dinas Tanaman Pangan Hortikultura dan Perkebunan Kabupaten Muna, menjelaskan, terkait dengan agenda peningkatan pertumbuhan ekonomi dan pendapatan hasil daerah memiliki fokus pada komoditas, jagung, padi, kedelai, kacang tanah, Ubi kayu, tomat, cabe, bawang merah, mente, coklat, kelapa dan kopi. Kementan dalam kunjungannya ke Kab. Muna mendorong masyarakat Kab. Muna mandiri dalam sayuran dengan memanfaatkan lahan yang tidak termanfaatkan untuk pertanian termasuk sayuran. Kab. Muna merupakan daerah yang potensial untuk sektor pertanian hortikultura namun kecenderungan produktivitas hasil tanaman hortikultura masih tergolong rendah disebabkan oleh terbatasnya sumber air, rendahnya keterampilan petani dan penerapan teknologi, lemahnya kelembagaan petani, permodalan, dan pemasaran, serangan hama penyakit, dan kurangnya dukungan sarana dan prasarana serta pemanfaatan lahan pertanian yang belum optimal. Di pihak lain, kebutuhan akan komoditas sayuran semakin meningkat seiring dengan bertambahnya jumlah penduduk dan berkembangnya teknologi pengolahan pangan.

5. Agribisnis Sayuran di Kabupaten Konawe

Kabupaten Konawe terletak di Unaaha yang berjarak $73 \mathrm{~km}$ ke arah barat dari kota Kendari ibukota Provinsi Sulawesi Tenggara Potensi Pertanian lahan kering Kabupaten Konawe memiliki areal baku (existing area) seluas 282.761 hektar, ,Kab.Konawe termasuk salah satu daerah Lumbung pangan di Sulawesi Tenggara karena salah satu daerah pendukung produksi padi di Sultra. Selain memiliki potensi lahan yang masih cukup luas, juga didukung oleh jaringan irigasi yang mampu memenuhi kebutuhan air bagi petani padi pada setiap musim tanam. Berdasarkan data yang dirilis Dinas Tanaman Pangan Hortikultura dan Perkebunan Kabupaten Konawe, luas sawah produktif saat ini mencapai 42.750 Hektar, Disamping itu dengan ketersedian air yang cukup petani Kab. Konawe selain bertani sawah sebagian berkebun dengan menanam sayuran. Diantara jenis sayuran yang diusahakan antara lain, Cabai, petai, bayam, kacang panjang, terong dll. Oleh karena itu Kab. Konawe Selatan dan Kab. Konawe merupakan suplai sayuran terbesar untuk masyarakat yang ada Kota Kendari sebagai Ibukota Provinsi Sulawesi Tenggara karena jarak yang dekat dibanding kabupaten yang lain yang ada di 
Sulawesi Tenggara sehingga pengembangan sayuran di Kab. Konawe perlu ditingkatkan untuk memenuhi kebutuhan penduduk Kota kendari semakin meningkat.

6. Prospek dan Arah Pengembangan Agribisnis

Perubahan lingkungan strategi, seperti globalisasi ekonomi, otonomi daerah, serta tuntutan masyarakat dunia terhadap keamanan pangan dan kelestarian lingkungan, mendorong adanya perubahan dalam agribisnis sayuran. Sayuran harus diproduksi secara efisien untuk dapat bersaing di pasar global. Menurut Kum- bhakar dan Lovell (2000), ada tiga cara efisiensi untuk memaksimumkan pendapatan usaha tani, yaitu efisiensi teknis, efisiensi masukan, dan efisiensi produksi.

Bertitik tolak dari efisiensi tersebut, pengembangan agribisnis sayuran perlu didukung kebijakan teknis yang berorientasi kepada: 1) pengembangan agribisnis sayuran melalui pola kemitraan, 2) konsolidasi kelembagaan di tingkat petani, 3) peningkatan keterkaitan antara sektor pertanian dan sektor industri serta sektor lainnya, dan 4) peningkatan kerja sama organisasi profesi dalam peningkatan agribisnis sayuran. Peningkatan daya saing harus berorientasi kepada penguasaan iptek melalui penerapan inovasi, peningkatan kompetensi SDM, perbaikan efisiensi, penciptaan iklim usaha yang kondusif untuk merangsang investasi, dan mengubah orientasi usaha Bertitik tolak dari efisiensi tersebut, pengembangan agribisnis sayuran perlu didukung kebijakan teknis yang ber- orientasi kepada: 1) pengembangan agribisnis sayuran melalui pola kemitraan, dari pendekatan produksi ke pendekatan daya saing.

Dukungan Pemerintah dalam pengembangan Agribisnis semakin besar dengan berbagai bantuan baik fisi maupun non fisik. Direktorat Budidaya Sayuran dan Biofarmaka (2006) telah menerbitkan pedoman budi daya sayuran yang baik. Pedoman budi daya ini mencakup penerapan teknologi ramah lingkungan, peningkatan keamanan pangan dan kesehatan, peningkatan kesejahteraan pekerja, pencegahan penularan OPT, dan penerapan prinsip traceability (penelusuran asal-usul suatu produk, dari pasar sampai kebun). Kepatuhan terhadap budi daya yang baik sangat diperlukan untuk memperoleh efisiensi usaha tani, kualitas produksi, keuntungan maksimal, keberlanjutan produksi, dan kelestarian sumber daya pertanian. Pengendalian hama dan penyakit yang ramah lingkungan melalui pengelolaan hama terpadu termasuk bagian penting yang perlu diterapkan oleh petani. Dalam menerapkan pedoman teknik budi daya ini, petani harus mulai membiasakan diri untuk mencatat seluruh aktivitas usaha taninya, termasuk sejarah lahan, tanggal tanam, varietas yang ditanam, pengen- 
dalian OPT yang digunakan, dan informasi penting lainnya. Penerapan prinsip budi daya yang baik dapat membantu petani untuk meningkatkan mutu produk dan mendorong peningkatan harga jual yang pada akhirnya dapat meningkatkan kesejahteraan petani.

Berdasarkan Peraturan Menteri Pertanian No. 61/Permentan/OT.140/ 10/2010 tanggal 14 Oktober 2010 tentang Organisasi dan Tata Kerja Kementerian Pertanian, Direktorat Budidaya dan Pascapanen Sayuran dan Tanaman Obat mempunyai tugas pokok melaksanakan penyiapan perumusan dan pelaksanaan kebijakan, penyusunan norma, standar, prosedur, dan kriteria, serta pemberian bimbingan teknis dan evaluasi di bidang budidaya dan pascapanen sayuran dan tanaman obat. Dalam melaksanakan tugasnya, Direktorat Budidaya dan Pascapanen Sayuran dan Tanaman Obat menyelenggarakan salah satu fungsi yaitu melakukan bimbingan teknis dan evaluasi di bidang budidaya dan pascapanen tanaman sayuran, tanaman obat dan jamur. Bimbingan teknis diberikan melalui pendampingan, bimbingan terhadap pelaku usaha sayuran dan tanaman obat di daerah sentra produksi serta pembinaan pengembangan tanaman sayuran dan tanaman obat. Kegiatan pembinaan pengembangan tanaman sayuran dan tanaman obat dilaksanakan di Provinsi pada suatu kawasan/wilayah. Kawasan adalah suatu kesatuan wilayah dengan kesamaan ekosistem dan disatukan oleh fasilitas infrastruktur ekonomi yang sama sehingga membentuk kawasan yang berisi berbagai kegiatan usaha mulai dari penyediaan sarana produksi, budidaya, penanganan pascapanen, dan pemasaran serta berbagai kegiatan pendukungnya. Kegiatan pembinaan yang dilakukan juga diharapkan dapat meningkatkan kemampuan SDM sayuran dan tanaman obat dalam rangka menghadapi Era Pasar Bebas pada saat ini, yang menghendaki produk sayuran dan tanaman obat yang aman konsumsi, bermutu dan ramah lingkungan dengan harga yang kompetitif sehing pada gilirannya, produk dalam negeri diharapkan dapat merebut pangsa pasar dalam negeri maupun luar negeri. Aspek kelembagaan petani juga sangat berperan dalam membangun sistem agribisnis hortikultura sehingga perlu diperhatikan dan dikembangkan seiring dengan semakin meningkatnya skala usaha dan jejaring kerjasama antar pelaku usaha. Pemberdayaan kelembagaan petani ditujukan untuk menciptakan kelembagaan yang responsif, dinamis dan berkelanjutan. Pengembangan kemandirian pelaku usaha menjadi prioritas untuk mempersiapkan para pelaku usaha sayuran dan tanaman obat yang tangguh. Upaya memandirikan usaha agribisnis sayuran dan tanaman obat, seringkali dihadapkan kepada ragam dan pola pemberdayaan kelembagaan yang belum profesional. Untuk itu sangat diperlukan pembinaan kelembagaan usaha dalam upaya mendorong berkembangnya 
kelembagaan usaha untuk bermitra dengan lembaga permodalan dan pemasaran, menuju kelembagaan usaha yang mandiri. Memperbaiki dan memperkuat posisi tawar petani melalui kelembagaan merupakan suatu kebutuhan yang sangat mendesak dan mutlak diperlukan oleh petani, agar mereka dapat bersaing dalam melaksanakan kegiatan usahatani dan dapat meningkatkan kesejahteraan hidupny.

Pengembangan komoditas sayuran ke depan akan berorientasi pada pemenuh- an standar mutu hasil, melalui penerapan cara budi daya yang benar atau good farming practices (GFP). Hal ini merupakan bagian dari sistem jaminan mutu (quality assurance system) dan keamanan pangan. Komoditas sayuran yang prospektif untuk dikembangkan saat ini antara lain adalah kubis, kentang, dan wortel. Cara budi daya sayuran yang benar prospektif untuk diterapkan mengingat pemerintah memberikan dukungan kebijakan yang kondusif dan tersedianya lahan yang sesuai, iklim yang kondusif, kesediaan petani menanam sayuran, jaminan pasar dengan harga yang kompetitif, dan tersedianya infrastruktur pengembangan agribisnis sayuran.

\section{KESIMPULAN DAN SARAN}

Analisis SWOT pengembangan agribisnis sayuran memperoleh empat strategi yang perlu dilakukan, yaitu: 1) strategi bisnis sayuran memperoleh empat strategi yang perlu dilakuk agresif (S-O), memaksimalkan potensi/ kekuatan untuk meraih peluang optimal dengan pemanfaatan teknologi produksi, perluasan dan pemanfaatan lahan secara optimal dan pangsa pasar, kebijakan pemerintah/pengembangan kelembagaan usaha agribisnis, dan peningkatan kualitas SDM, 2) strategi diversifikasi (S-T), memaksimalkan potensi/kekuatan untuk mengurangi ancaman yang ada, dengan melakukan kegiatan usaha tani yang ramah lingkungan, pemberdayaan penangkar benih, dan penerapan PHT, 3) strategi divestasi (W-O), meminimalkan kelemahan/hambatan untuk meraih peluang semaksimal mungkin serta meningkatkan produksi/produktivitas dan mutu produk, penguatan sarana usaha pertanian, diversifikasi, dan pengaturan pola tanam sesuai permintaan pasar, 4) strategi survival (W-T), meminimalkan kelemah- an dan hambatan untuk meminimalkan ancaman dengan meningkatkan efisiensi biaya produksi, memperluas informasi pasar, dan meminimalkan pemakaian input kimia.

Strategi pengembangan agribisnis sayuran berkelanjutan ke depan adalah melakukan reorientasi sistem pengelolaan tanaman, sinergi dan harmonisasi inovasi budi daya, serta mengembangkan kerja sama kemitraan. Strategi diarahkan pada upaya mengembangkan produksi sesuai dengan kebutuhan, menciptakan pola tanam yang merata sepanjang tahun, 


\section{Jurnal: Inovasi Sains dan Teknologi (INSTEK)}

ISSN: 2655-0563, Edisi: Vol 2, No 2, Agustus 2019

meningkatkan daya saing dan kemampuan SDM, menguatkan kelembagaan petani, permodalan, dan pemasaran, serta meng- optimalkan penggunaan lahan serta sarana dan prasarana. Peningkatan produktivitas dan kualitas sayuran memerlukan dukungan kebijakan pemerintah, khususnya subsidi sarana produksi bagi petani serta upaya menerapkan pedoman budi daya sayuran.

\section{DAFTAR PUSTAKA}

BPS Kabupaten Konawe Selatan. 2008. Kabupaten Konawe Selatan dalam Angka. Badan Pusat Statistik Kabupaten Konawe Selatan.

BPS Kabupaten Konawe 2018. Kabupaten Konawe dalam Angka. Badan Pusat Statistik Kabupaten Konawe

BPS Kabupaten Muna 2017. Kabupaten Muna dalam Angka. Badan Pusat Statistik Kabupaten Muna

BPS Sulawesi Tenggara. 2018. Sulawesi Tenggara dalam Angka. Badan Pusat Statistik Provinsi Sulawesi Tenggara, Kendari.

BPS Sulawesi Tenggara. 2017. Sulawesi Tenggara dalam Angka. Badan Pusat Statistik Sulawesi Tenggara, Kendari.

BPS Sulawesi Tenggara. 2018. Luas Panen Tanaman Sayuran Per Kabupaten Provinsi Sulawesi Tenggara Tahun 2016. Badan Pusat Statistik Sulawesi Tenggara, Kendari

BPS Sulawesi Tenggara. 2017. Statistik Produksi Tanaman Hortukultura Provinsi Sulawesi Tenggara Tahun 2017. Badan Pusat Statistik Provinsi Sulawesi Tenggara, Kendari

BMKG dan Kementan Dkk. 2017. Iklim dan Ketahanan Pangan. Buletin Pemantauan Ketahanan Pangan Indonesia. Jakarta

Dinas Pertanian perkebunan dan Hortikultura Sulawesi Tenggara Tahun 2018. Pengembangan Sektor Tanaman Perkebunan dan Hortikutura Provinsi Sulawesi Tenggara, Kendari

Dinas Pertanian Tanaman Pangan Kabupaten Konawe 2017. Laporan Tahunan. Dinas Pertanian Tanaman Pangan Kabupaten Konawe. Unaaha

Dinas Pertanian Tanaman Pangan Kabupaten Konawe Selatan. 2018. Laporan Tahunan. Dinas Pertanian Tanaman Pangan Kabupaten Konawe Selatan. Andoolo

Dinas Pertanian Tanaman Pangan Kabupaten Muna. 2017. Laporan Tahunan. Dinas Pertanian Tanaman Pangan Kabupaten Muna. Raha

Direktorat Budidaya Sayuran dan Biofarmaka. 2006. Pedoman Budidaya Sayuran yang Baik (Good Agricultural Practices). Direktorat Budidaya Sayuran dan Biofarmaka, Direktorat Jenderal Hortikultura, Jakarta. 39 hlm.

Duriat, A.S. 1995. Hasil-hasil Penelitian Cabai Merah Pelita V. Pusat Penelitian dan Pengembangan Hortikultura, Jakarta.

Hendayana, R. 2011. Metode Analisis Data Hasil Pengkajian. Balai Besar Pengkajian dan Pengembangan Teknologi Pertanian, Bogor. 
Kementan Dorong Konawe Selatan jadi Lumbung Komoditi Hortikultura. Andoolo, Http://www. Agronet.co.id

Balitbang Kementerian desa \& PDT. 2017 Buku Data dan Informasi Produk Unggulan di daerah tertinggal Kab. Muna.. Pusat Data dan Informasi Balitbang Kementerian desa \& PDT. Jakarta

Rangkuti, F. 1997. Analisis SWOT, teknik membedah kasus bisnis. PT Gramedia Pustaka Utama, Jakarta.

Saptana, T. Pranadji, Syahyuti, dan Roosgandha. 2002. Transformasi Kelembagaan Tradisional. Pusat Penelitian dan Pengembangan Sosial Ekonomi Pertanian, Bogor.

Saptana, A. Daryanto, H.K. Daryanto, dan Kuncoro. 2009. Strategi kemitraan usaha dalam rangka peningkatan daya saing agribisnis cabai merah di Jawa Tengah. Makalah pada Seminar Nasional Peningkatan Daya Saing Agribisnis Berorientasi Kesejahteraan Petani, Bogor, 14 Oktober 2009. Pusat Analisis Sosial Ekonomi dan Kebijakan Pertanian, Bogor.

Saragih, B. 1998. Agribisnis. Paradigma Baru Pembangunan Ekonomi Berbasis Pertanian. Lembaga Penelitian Institut Pertanian Bogor, Bogor.

Taufik M 2012. Prospek dan Strategi Pengembangan Sayuran Provinsi Sulawesi Selatan. Balai Pengkajian Teknologi Pertanian Sulawesi Selatan. Makassar 